\title{
Influenza virus infection among pediatric patients reporting diarrhea and influenza-like illness
}

\author{
Charisma Dilantika ${ }^{1}$, Endang R Sedyaningsih², Matthew R Kasper ${ }^{1 *}$, Magdarina Agtini², Erlin Listiyaningsih', \\ Timothy M Uyeki ${ }^{3}$, Timothy H Burgess ${ }^{1}$, Patrick J Blair ${ }^{1}$, Shannon D Putnam
}

\begin{abstract}
Background: Influenza is a major cause of morbidity and hospitalization among children. While less often reported in adults, gastrointestinal symptoms have been associated with influenza in children, including abdominal pain, nausea, vomiting, and diarrhea.

Methods: From September 2005 and April 2008, pediatric patients in Indonesia presenting with concurrent diarrhea and influenza-like illness were enrolled in a study to determine the frequency of influenza virus infection in young patients presenting with symptoms less commonly associated with an upper respiratory tract infection (URTI). Stool specimens and upper respiratory swabs were assayed for the presence of influenza virus.

Results: Seasonal influenza A or influenza B viral RNA was detected in 85 (11.6\%) upper respiratory specimens and 21 (2.9\%) of stool specimens. Viable influenza B virus was isolated from the stool specimen of one case. During the time of this study, human infections with highly pathogenic avian influenza A ( $\mathrm{H} 5 \mathrm{~N} 1$ ) virus were common in the survey area. However, among 733 enrolled subjects, none had evidence of H5N1 virus infection.

Conclusions: The detection of influenza viral RNA and viable influenza virus from stool suggests that influenza virus may be localized in the gastrointestinal tract of children, may be associated with pediatric diarrhea and may serve as a potential mode of transmission during seasonal and epidemic influenza outbreaks.
\end{abstract}

\section{Background}

Influenza is a major cause of morbidity and hospitalization among children [1-5]. Complications of influenza among children are well-documented, including bronchiolitis, pneumonia, as well as neurological manifestations such as acute encephalopathy and encephalitis [6]. While less often reported in adults, gastrointestinal symptoms have been associated with influenza in children, including abdominal pain, nausea, vomiting, and diarrhea $[7,8]$. One study reported detection of influenza viral RNA in rectal swabs from two infants confirmed with influenza disease [9].

Diarrhea has been reported among confirmed influenza A (H5N1) cases $[10,11]$, in some cases preceding lower respiratory tract involvement [12-14]. Detection of influenza A (H5N1) viral RNA and the isolation and identification of influenza A (H5N1) virus, in cell culture, has been reported from rectal swab, stool, and

\footnotetext{
* Correspondence: kaspernamru2@yahoo.com

${ }^{1}$ Naval Medical Research Unit No. 2, Jakarta, Indonesia
}

enteral tissue specimens from fatal, confirmed A (H5N1) cases [15-17]. Despite the recognized clinical association between these enteric manifestations and influenza, limited data are available about whether influenza viruses are present in the gastrointestinal tract of children with influenza-like illness.

Influenza activity occurs year-round in Indonesia, with increased activity during the rainy season (November through April) and peaking in December-January [18]. In addition to seasonal influenza, Indonesia has reported the highest number of influenza A (H5N1) cases worldwide ( $\mathrm{N}=139$, December 2008; http://www.who.int), with a case fatality proportion reported between $75 \%$ and $80 \%[19,20]$. The epidemiology of human cases of influenza A (H5N1) in Indonesia shows that $96 \%$ of the cases occurred in persons $<40$ years of age, $24 \%<10$ years of age, with a median age 18.5 years; nearly twothirds were classified as rural inhabitants [19].

The primary objective of this study was to determine the prevalence of seasonal influenza $A$ and $B$ viruses, and avian influenza A (H5N1) virus, among children 
seeking medical care with acute influenza-like illness (ILI) and diarrhea in Indonesia.

\section{Methods}

\section{Study site and population}

Children $<6$ years of age with concurrent diarrhea and acute influenza-like illness presenting at any of 12 study sites (Indonesian Pediatric Diarrhea Network) between September 2005 and April 2008 were eligible for enrollment. Including in the Indonesian Pediatric Diarrhea Network were established study sites located in Jakarta, West Java; Yogyakarta, Central Java; Denpasar, Bali; Mataram, Lombok; Makassar, Sulawesi and Medan, North Sumatra. Stool and upper respiratory (nasal swab and throat swab) specimens were collected from each participant after informed consent was obtained. Nasal swab specimens were collected from the mid-turbinate region and the swab was placed in 2-3 $\mathrm{ml}$ of viral transport media (VTM). For throat swabs, both tonsils and the posterior pharynx were swabbed vigorously, and the swab placed in 2-3 ml of VTM. Collected specimens were placed into viral transport media and shipped on ice packs to the laboratory via air or ground courier, within 24 hours after collection. Upon arrival specimens were stored at $-70^{\circ} \mathrm{C}$ until testing. Influenza-like illness was defined as acute fever $\left(>38.0^{\circ} \mathrm{C}\right)$ with cough or sore throat; diarrhea was defined as three or more loose/liquid stools or two or more loose/liquid stools with one or more associated enteric symptoms (e.g., nausea, vomiting, abdominal cramps, or bloody stool) during any 24 hour period of the current episode. Seasonality was defined as either 'rainy' season (November through April) or 'dry' season (May through October) for this study.

\section{Laboratory testing}

Specimen testing was conducted at a central laboratory in Jakarta, Indonesia. RNA was extracted from VTM of throat and nasal swab specimens and stool specimens resuspended in a $10 \%$ solution of PBS using the QIAmp viral RNA mini kit (Qiagen, Hilden, Germany). Identification of influenza type and influenza A subtypes was conducted using multiplex nested reverse-transcription polymerase chain reaction (RT-PCR) as previously described [21,22]. Based on RT-PCR results, a random sample of positive clinical specimens was selected for viral isolation; a random sample of negative specimens was sent for viral culture as well. Briefly, specimens were inoculated onto Madin-Darby canine kidney (MDCK) tissue cells with an aliquot of clinical specimens and incubated for 7 days; indirect immunofluorescence assay (IFA) using specific influenza labeled antibodies was employed to confirm the presence of influenza.

\section{Data analysis}

All data was double-entered into a MS Access (Microsoft Corp., Redmond, Washington, USA) database and statistical testing was conducted using SAS 9.1.13 (SAS Institute, Cary North Carolina, USA).

\section{Ethical Considerations}

This study was reviewed and approved by the Ethical Commission of the National Institute of Health Research and Development, Indonesian Ministry of Health, Jakarta, Indonesia and by the Institutional Review Board for the ethical conduct of research on human subjects at the U.S. Naval Medical Research Unit No. 2, Jakarta, Indonesia.

\section{Results}

\section{Characteristics of patients}

From September 2005 through April 2008, 733 pediatric patients $(<6$ years of age) with diarrhea and influenzalike illness were enrolled. Each participant provided matched clinical specimens (stool, one nasal swab and one throat swab) for laboratory analysis. The median age of participants was 15 months (interquartile range (IQR), 9 - 24 months) and 59.5\% (436) were male. The median duration of the enrollment diarrhea episode was 1 day (IQR, 1 - 2 days). The median duration of current influenza-like illness episode was 2 days (IQR, 1 - 2). Malnutrition and dehydration among the study participants, subjectively assigned by the enrolling physician, was $7.4 \%$ and $25.8 \%$, respectively. Diarrhea severity was subjectively defined by the physician and $71.5 \%$ of the study participants were assigned as having either 'mild' or 'moderate' diarrhea. Of the 733 study participants, 80 (10.9\%) were hospitalized, 11 (1.5\%) tested positive for influenza virus by RT-PCR. Table 1 lists the sampling demographics, signs and symptoms, severity of illness and other covariates, stratified by specimen site.

\section{Influenza detection}

Of 733 study participants, influenza virus was detected by RT-PCR in 85 (11.6\%) upper respiratory tract specimens and $21(2.9 \%)$ stool specimens. Only six patients had concurrent influenza virus identified from both upper respiratory and stool specimens. Of the 100 patients that tested positive for influenza, influenza $\mathrm{A}$ and influenza B virus accounted for $40(40.0 \%)$ and 60 (60.0\%), respectively. Of the influenza A viruses identified in upper respiratory specimens, 13 were $A(\mathrm{H} 1 \mathrm{~N} 1)$ and 27 were $A(\mathrm{H} 3 \mathrm{~N} 2)$. Both influenza $A$ and $B$ viruses were detected in stool specimens, including one A (H1N1), three A (H3N2), and 17 B viruses by PCR. In addition to the molecular detection of influenza viral RNA, a subset of randomly selected PCR positive and PCR negative samples (18 and 38 , respectively) were submitted for viral culture with a total of 15 (26.8\%) positive from upper respiratory specimens. From 25 stool specimens (13 positive and 12 negative by PCR) there was one $(4.0 \%)$ positive. There were no PCR negative samples that tested positive by viral culture. 
Table 1 Demographics, signs and symptoms of study participants stratified by clinical specimen site $(\mathbf{n}=\mathbf{7 3 3})$.

\begin{tabular}{|c|c|c|c|c|}
\hline & $\begin{array}{c}\text { Stool } \\
(N=15)\end{array}$ & $\begin{array}{c}\text { Upper Respiratory }{ }^{\mathrm{a}} \\
(\mathrm{N}=79)\end{array}$ & $\begin{array}{c}\text { Both } \\
(\mathrm{N}=6)\end{array}$ & $\begin{array}{l}\text { Neither } \\
(\mathrm{N}=633)\end{array}$ \\
\hline $\operatorname{Age}^{\mathrm{b}}$ (months) & $12(9-15)$ & $19(10-27)$ & $9(5-27)$ & $14(8-23)$ \\
\hline Diarrhea duration ${ }^{\mathrm{b}}$ (days) & $2(1-3)$ & $1(1-2)$ & $1(1-2)$ & $1(1-2)$ \\
\hline Influenza-like illness duration ${ }^{\mathrm{b}}$ (days) & $3(1-4)$ & $2(1-3)$ & $2(2-3)$ & $2(1-3)$ \\
\hline Fever duration ${ }^{b}$ (days) & $2(1-2)$ & $1(1-2)$ & $1(1-3)$ & $1(1-2)$ \\
\hline \multicolumn{5}{|l|}{ Gender $^{c}$} \\
\hline Male & $10(66.7 \%)$ & $44(55.7 \%)$ & $3(50.0 \%)$ & $379(59.9 \%)$ \\
\hline Female & $5(33.3 \%)$ & $35(44.3 \%)$ & $3(50.0 \%)$ & $254(40.1 \%)$ \\
\hline \multicolumn{5}{|l|}{$\mathrm{Age}^{\mathrm{c}}$ (months) } \\
\hline $0-5$ & $0(0.0 \%)$ & $2(2.5 \%)$ & $2(33.3 \%)$ & $65(10.3 \%)$ \\
\hline $6-11$ & $5(33.3 \%)$ & $24(30.4 \%)$ & $1(0.0 \%)$ & $176(27.8 \%)$ \\
\hline $12-23$ & $8(53.3 \%)$ & $23(29.1 \%)$ & $0(0.0 \%)$ & $234(37.0 \%)$ \\
\hline $24-35$ & $1(6.7 \%)$ & $16(20.3 \%)$ & $3(50.0 \%)$ & $92(14.5 \%)$ \\
\hline $36-46$ & $0(0.0 \%)$ & $7(8.9 \%)$ & $0(0.0 \%)$ & $37(5.8 \%)$ \\
\hline $47-71$ & $1(6.7 \%)$ & 7 (8.9\%) & $0(0.0 \%)$ & $29(4.6 \%)$ \\
\hline \multicolumn{5}{|l|}{ Diarrhea Severity ${ }^{c}$} \\
\hline Mild & $4(26.7 \%)$ & $29(36.7 \%)$ & $2(33.3 \%)$ & $166(26.7 \%)^{d}$ \\
\hline Moderate & $10(66.7 \%)$ & $28(35.4 \%)$ & $3(50.0 \%)$ & $274(44.1 \%)^{d}$ \\
\hline Severe & $1(6.7 \%)$ & $21(26.6 \%)$ & $1(16.7 \%)$ & $182(29.2 \%)^{d}$ \\
\hline Malnutrition ${ }^{c}$ & $1(6.7 \%)$ & $8(11.3 \%)^{d}$ & $0(0.0 \%)^{d}$ & $41(7.0 \%)^{d}$ \\
\hline Fever $^{c}$ & 15 (100\%) & 79 (100\%) & $6(100 \%)$ & $633(100 \%)$ \\
\hline Cough $^{c}$ & 15 (100\%) & $76(96.2 \%)$ & $6(100 \%)$ & 609 (96.2\%) \\
\hline Hospitalization ${ }^{c}$ & $2(13.3 \%)$ & $8(10.1 \%)$ & $1(16.7 \%)$ & 69 (10.9\%) \\
\hline
\end{tabular}

a. Upper respiratory is a composite variable of throat and nasal specimen.

b. Results presented as median (interquartile range)

c. Results presented as number (percent)

d. Percent values reflect missing denominator data

\section{Discussion}

To our best of our knowledge, this is the largest study investigating influenza virus detection in the gastrointestinal tract of children with influenza-like illness and diarrhea. This study found evidence of influenza viral RNA in $21(2.9 \%)$ stool specimens collected from pediatric patients aged $<6$ years presenting with influenza-like illness (ILI) and diarrhea, thus confirming the findings of a very small study in young children aged 0 - 23 months [9]. The successful recovery of viable influenza B virus from the stool of a single case was notable; it is not clear whether detection of influenza virus in the stool represents active infection of the gastrointestinal tract or swallowed virus from an upper respiratory tract infection. It is possible that influenza viruses might bind to $\alpha 2,6$ sialic acid receptors in the human gastrointestinal tract, and infect and actively replicate within cells in the gastrointestinal tract [23], similar to influenza viruses replication in avian species. However, two studies did not find any evidence for human influenza virus receptors in epithelial cells of the intestinal tract $[24,25]$. Of interest, influenza virus was the only pathogen detected in several cases of diarrheic children with ILI. Studies are being planned to further confirm these findings and investigate the gastrointestinal activity of influenza virus among influenza positive patients.

We did not detect highly pathogenic avian influenza A (H5N1) viral RNA from any clinical specimens, even though fever and diarrhea have been reported as presenting signs and symptoms in some $\mathrm{H} 5 \mathrm{~N} 1$ patients $[13,14,19]$. During the study period, Indonesia reported the highest number of H5N1 human cases of any country http://www.who.int, and $\mathrm{H} 5 \mathrm{~N} 1$ is endemic among 
poultry in Indonesia, human infection with $\mathrm{H} 5 \mathrm{~N} 1$ virus continues to be a rare event.

The low yield of influenza virus detected from stool could be due to several factors. It is possible that influenza virus infection and viral shedding in the gastrointestinal tract may be truly low in children with influenza. It is also possible that detection of influenza virus in stool or rectal swab specimens, either by RTPCR or viral culture, may have been reduced due to inhibitory material present in the gastrointestinal tract and stool. Alternatively, the amount of time, transport time, between specimen collection and inoculation may have rendered the viruses non-viable and subsequently had degradation of influenza target. Additional studies are warranted to further investigate influenza virus detection, including the swine-origin influenza A virus $[26,27]$, in stool specimens of acute ILI patients with and without diarrhea. In addition, studies that further examine influenza virus binding to intestinal tract epithelial tissue, and replication of influenza viruses within the gastrointestinal tract are needed.

\section{Conclusions}

The detection of influenza viral RNA and viable influenza virus from stool suggests that influenza virus may be localized in the gastrointestinal tract of children, may be associated with pediatric diarrhea and may serve as a potential mode of transmission during seasonal and epidemic influenza outbreaks.

\section{Acknowledgements}

The authors would like to thank all participating hospitals and clinics in the Indonesian Pediatric Diarrhea Surveillance Network. In addition, we thank all the laboratory technicians who participated in the processing of all clinical specimens; both at NAMRU2 and the National Institute of Health Research and Development, Ministry of Health. No conflicts of interest exist among any of the authors. Preliminary data for this manuscript was presented by the primary author at the 6th Annual Options for the Control of Influenza in Toronto, Canada, June 2007.

Funding for this study was provided by the Global Emerging Infections Surveillance and Response System, a Division of the Armed Forces Health Surveillance Center and the U.S. State Department's Biosecurity Engagement Program.

Views expressed in this article are those of the authors and do not reflect the official policy or position of the Government of Indonesia, Indonesian Ministry of Health, Indonesian National Institute of Health Research and Development, the U.S. Department of Defense, the Department of the Navy or U.S. Naval Medical Research Unit No. 2, Jakarta, Indonesia, or the US Centers for Disease Control and Prevention.

Author details

${ }^{1}$ Naval Medical Research Unit No. 2, Jakarta, Indonesia. ${ }^{2}$ Center for Biomedical and Pharmaceutical Research and Development, National Institute of Health Research and Development, Jakarta, $\mathrm{MOH}$ Indonesia. ${ }^{3}$ Epidemiology and Prevention Branch, Influenza Division, Centers for Disease Control and Prevention, Atlanta, Georgia, USA.
}

\section{Authors' contributions}

CD - laboratory supervision and testing, data analysis, writing manuscript. ERS - Study design, review and corrections of manuscript. MRK - Data analysis, writing manuscript, revisions to manuscript. MA - study oversight, data management and analysis. EL - Study oversight and supervision of laboratory testing. TMU - Study design, review and corrections of manuscript. THB - Study design, review and corrections of manuscript. PJB Study design, review and corrections of manuscript. SDP - study principal investigator (Sept 2005 - April 2008), study design and implementation, data management, data analysis, writing manuscript. All authors read and approved the final manuscript.

\section{Competing interests}

The authors declare that they have no competing interests.

Received: 6 August 2009

Accepted: 7 January 2010 Published: 7 January 2010

\section{References}

1. Coffin SE, Zaoutis TE, Rosenquist AB, Heydon K, Herrera G, Bridges CB, Watson B, Localio R, Hodinka RL, Keren R: Incidence, complications, and risk factors for prolonged stay in children hospitalized with communityacquired influenza. Pediatrics 2007, 119:740-748.

2. Louie JK, Schechter R, Honarmand S, Guevara HF, Shoemaker TR, Madrigal NY, Woodfill CJ, Backer HD, Glaser CA: Severe pediatric influenza in California, 2003-2005: implications for immunization recommendations. Pediatrics 2006, 117:e610-618.

3. Bhat N, Wright JG, Broder KR, Murray EL, Greenberg ME, Glover MJ, Likos AM, Posey DL, Klimov A, Lindstrom SE, et al: Influenza-associated deaths among children in the United States, 2003-2004. N Engl J Med 2005, 353:2559-2567.

4. Poehling KA, Edwards KM, Weinberg GA, Szilagyi P, Staat MA, Iwane MK, Bridges CB, Grijalva CG, Zhu Y, Bernstein Dl, et al: The underrecognized burden of influenza in young children. N Engl J Med 2006, 355:31-40.

5. Schrag SJ, Shay DK, Gershman K, Thomas A, Craig AS, Schaffner W, Harrison LH, Vugia D, Clogher P, Lynfield R, et al: Multistate surveillance for laboratory-confirmed, influenza-associated hospitalizations in children: 2003-2004. Pediatr Infect Dis J 2006, 25:395-400.

6. Morishima T, Togashi T, Yokota S, Okuno Y, Miyazaki C, Tashiro M, Okabe N: Encephalitis and encephalopathy associated with an influenza epidemic in Japan. Clin Infect Dis 2002, 35:512-517.

7. Wang YH, Huang YC, Chang LY, Kao HT, Lin PY, Huang CG, Lin TY: Clinical characteristics of children with influenza $A$ virus infection requiring hospitalization. J Microbiol Immunol Infect 2003, 36:111-116.

8. Liou YS, Barbour SD, Bell LM, Plotkin SA: Children hospitalized with influenza B infection. Pediatr Infect Dis J 1987, 6:541-543.

9. Wootton SH, Scheifele DW, Mak A, Petric M, Skowronski DM: Detection of human influenza virus in the stool of children. Pediatr Infect Dis J 2006, 25:1194-1195.

10. Abdel-Ghafar AN, Chotpitayasunondh T, Gao Z, Hayden FG, Nguyen DH, de Jong MD, Naghdaliyev A, Peiris JS, Shindo N, Soeroso S, Uyeki TM: Update on avian influenza $\mathrm{A}(\mathrm{H} 5 \mathrm{~N} 1)$ virus infection in humans. $N$ Engl J Med 2008, 358:261-273.

11. Tran TH, Nguyen TL, Nguyen TD, Luong TS, Pham PM, Nguyen VC, Pham TS, Vo CD, Le TQ, Ngo TT, et al: Avian influenza A (H5N1) in 10 patients in Vietnam. N Engl J Med 2004, 350:1179-1188.

12. Peiris JS, de Jong MD, Guan Y: Avian Influenza Virus (H5N1): a Threat to Human Health. Clin Microbiol Rev 2007, 20:243-267.

13. Apisarnthanarak $A$, Kitphati $R$, Thongphubeth $K$, Patoomanunt $P$ Anthanont P, Auwanit W, Thawatsupha P, Chittaganpitch M, Saeng-Aroon S, Waicharoen S, et al: Atypical avian influenza (H5N1). Emerg Infect Dis 2004, 10:1321-1324.

14. de Jong MD, Bach VC, Phan TQ, Vo MH, Tran TT, Nguyen BH, Beld M, Le TP, Truong HK, Nguyen W, et al: Fatal avian influenza A (H5N1) in a child presenting with diarrhea followed by coma. N Engl J Med 2005, 352:686691.

15. de Jong MD, Simmons CP, Thanh TT, Hien VM, Smith GJ, Chau TN, Hoang DM, Chau NV, Khanh TH, Dong VC, et al: Fatal outcome of human influenza $A(\mathrm{H} 5 \mathrm{~N} 1)$ is associated with high viral load and hypercytokinemia. Nat Med 2006, 12:1203-1207.

16. Uiprasertkul M, Puthavathana P, Sangsiriwut K, Pooruk P, Srisook K, Peiris M, Nicholls JM, Chokephaibulkit K, Vanprapar N, Auewarakul P: Influenza A H5N1 replication sites in humans. Emerg Infect Dis 2005, 11:1036-1041. 
17. Buchy P, Mardy S, Vong S, Toyoda T, Aubin JT, Miller M, Touch S, Sovann L, Dufourcq JB, Richner $B$, et al: Influenza A/H5N1 virus infection in humans in Cambodia. J Clin Virol 2007, 39:164-168.

18. Beckett $C G$, Kosasih $H$, Ma'roef $C$, Listiyaningsih $E$, Elyazar IR, Wuryadi $S$, Yuwono D, McArdle JL, Corwin AL, Porter KR: Influenza surveillance in Indonesia: 1999-2003. Clin Infect Dis 2004, 39:443-449.

19. Sedyaningsih ER, Isfandari S, Setiawaty V, Rifati L, Harun S, Purba W, Imari S, Giriputra S, Blair PJ, Putnam SD, et al: Epidemiology of cases of H5N1 virus infection in Indonesia, July 2005-June 2006. J Infect Dis 2007, 196:522-527.

20. Kandun IN, Wibisono H, Sedyaningsih ER, Yusharmen, Hadisoedarsuno W, Purba W, Santoso H, Septiawati C, Tresnaningsih E, Heriyanto B, et al: Three Indonesian clusters of H5N1 virus infection in 2005. N Engl J Med 2006, 355:2186-2194.

21. Zhang WD, Evans DH: Detection and identification of human influenza viruses by the polymerase chain reaction. J Virol Methods 1991, 33:165189.

22. Gu J, Xie Z, Gao Z, Liu J, Korteweg C, Ye J, Lau LT, Lu J, Gao Z, Zhang B, et al: H5N1 infection of the respiratory tract and beyond: a molecular pathology study. Lancet 2007, 370:1137-1145.

23. Beigel JH, Farrar J, Han AM, Hayden FG, Hyer R, de Jong MD, Lochindarat $S$, Nguyen TK, Nguyen TH, Tran TH, et al: Avian influenza A (H5N1) infection in humans. N Engl J Med 2005, 353:1374-1385.

24. Sata T, Roth J, Zuber C, Stamm B, Heitz PU: Expression of alpha 2,6-linked sialic acid residues in neoplastic but not in normal human colonic mucosa. A lectin-gold cytochemical study with Sambucus nigra and Maackia amurensis lectins. Am J Pathol 1991, 139:1435-1448.

25. Yao L, Korteweg C, Hsueh W, Gu J: Avian influenza receptor expression in H5N1-infected and noninfected human tissues. Faseb J 2008, 22:733-740.

26. Dawood FS, Jain S, Finelli L, Shaw MW, Lindstrom S, Garten RJ, Gubareva LV, Xu X, Bridges CB, Uyeki TM: Emergence of a novel swineorigin influenza A (H1N1) virus in humans. N Engl J Med 2009, 360:26052615.

27. Shinde V, Bridges CB, Uyeki TM, Shu B, Balish A, Xu X, Lindstrom S, Gubareva LV, Deyde V, Garten RJ, et al: Triple-reassortant swine influenza A (H1) in humans in the United States, 2005-2009. N Engl J Med 2009, 360:2616-2625.

\section{Pre-publication history}

The pre-publication history for this paper can be accessed here:http://www. biomedcentral.com/1471-2334/10/3/prepub

doi:10.1186/1471-2334-10-3

Cite this article as: Dilantika et al:: Influenza virus infection among pediatric patients reporting diarrhea and influenza-like illness. BMC Infectious Diseases 2010 10:3.

\section{Publish with Bio Med Central and every scientist can read your work free of charge}

"BioMed Central will be the most significant development for disseminating the results of biomedical research in our lifetime. "

Sir Paul Nurse, Cancer Research UK

Your research papers will be:

- available free of charge to the entire biomedical community

- peer reviewed and published immediately upon acceptance

- cited in PubMed and archived on PubMed Central

- yours - you keep the copyright
BioMedcentral 